\title{
$\kappa_{b}^{0}$ Inter-American Notes $\frac{q}{2}$
}

\section{FELLOWSHIP ANNOUNCEMENT}

The Academy of American Franciscan History is pleased to announce that it has awarded its annual dissertation fellowship for 2004 to Nuno Senos of New York University. Mr. Senos's dissertation will be titled: "Franciscan Patronage in Northeastern Brazil (1650-1800)."

Applications for next year's fellowship competition are due February 1, 2006. For more information please contact the Academy of American Franciscan History, 1712 Euclid Ave., Berkeley, CA, 94709. Phone: (510) 548-1755, or consult their website: www.aafh.org

\section{OBITUARY \\ Mario Rodríguez \\ (1922-2005)}

Central America lost one of its most devoted voices on January 26, 2005, when Mario Rodríguez, scholar and teacher of Latin American history, died. A consummate professional and an innovator in the field, El Profe (as his students fondly dubbed him) will be sorely missed. Rodríguez's scholarly career had its beginnings in Colusa, California, where he was born in 1922, a son of Spanish immigrants. Educated in California schools, as a young man he entered the University of California at Berkeley. World War II interrupted his efforts to study literature, and when he returned he finished the M.A. in Spanish and Latin American literature. In 1952, under the guidance of his mentor, Engel Sluiter, he completed the Ph.D. in history. During the war, "Rod" (as he became commonly known) had been sent to study languages at the University of Illinois and the University of Grenoble, France. Once passed graduate work, he entered academe. His first position was a two-year stay at Tulane University, a focal point for Central American studies, after which he clocked longer stints at Yale University (1954-1960), the University of Arizona (1960-1966), the George Washington University (1966-1972), and thereafter coming home to the University of Southern California, where he spent the remainder of his illustrious career until his retirement in 1992. 
Over a forty-year career, Rodríguez was a prolific and well-recognized scholar. His major books included A Palmerstonian Diplomat in Central America: Frederick Chatfield, Esquire (University of Arizona Press, 1964), Central America (Prentice-Hall, 1965), the now-classic study, The Cadiz Experiment in Central America, 1808-1826 (University of California Press, 1984) and "William Burke" and Francisco de Miranda: The Word and the Deed in Spanish America's Emancipation (University Press of America, 1994). There were in addition numerous shorter monographs and articles. The Chatfield book drew enough attention in Central America to cause the Banco Central de Honduras to publish a translation in 1970, and in an unusual move to follow that with a second edition in 2003. Perhaps the best known of his articles were "The Livingston Codes in the Guatemalan Crisis of 1837-1838" (which appeared in a volume of essays he edited for the Tulane University Middle American Research Institute), Applied Enlightenment: 19th-Century Liberalism (1972), and the article that won the James Alexander Robertson Prize of the Conference on Latin American History, "The Genesis of Economic Attitudes in the Río de la Plata" (HAHR, 36:2 [1956]). For some years Rod held ambiguous feelings about that article, one of two based on his doctoral dissertation, especially the notice it received. He was truly proud of the recognition given to it by CLAH but the same article also was cited by Victor Volsky, a Soviet scholar, who mentioned it in a review article on historical trends in the United States as the single exception to an otherwise bland and predictable output of publications without much economic substance. In some quarters this laudatory comment labeled Rod as a Marxist and, given the McCarthyite political discourse dominant only a few years earlier in the United States, made it difficult for some to see beyond the tag. His scholarship continued nevertheless and over the next three decades he published a rash of articles, essays, chapters in books, over 55 book reviews, and historiographical contributions to major bibliographies in the United States and Central America. He willingly served the profession through stints as a contributing editor to the Handbook of Latin American Studies first for "Spanish South America" and later for "Central America," attesting to his determination to serve in as many ways as possible.

Rod's work won him recognition under other circumstances. The Robertson prize was followed quickly at Yale by the award of a Morse Fellowship in History (1958-1959), and a few years later while at Arizona he was the recipient of a John Simon Guggenheim Fellowship, which allowed him and his wife, Mildred, to spend the academic year 1964-1965 in Central America. Later he was honored with the Phi Kappa Phi Book Award at the University of Southern California in 1981 in recognition of his study of the impact of the Cadiz constitutional process in Central America.

Rod always denied that he was an administrator and he always was reluctant to take on the duties of the chair in the various departments in which he held appointments. Yet he exhibited clear administrative abilities at key points in his career. Notably, he steered a Latin American history course into being at Yale, the first person trained in the field to offer such a course there. His labors won Latin Amer- 
ican history the respect of his colleagues, thus laying the groundwork for its future growth in that department. His more obvious administrative capabilities emerged twice during his career. While he was at George Washington University he was instrumental in getting the Latin American Studies program organized and off the ground. Later he was the point man in the establishment of a Latin American Studies program at the University of Southern California. He always returned to the documents, however, and perhaps no research project gave him greater pleasure than the hunt for "William Burke." He discovered that Burke was James Mill, the father of John Stuart Mill, who in that critical era was writing about Latin American emancipation under a pseudonym.

El Profe had a profound, long lasting influence on his students, colleagues and 'friends. As a teacher as well as a researcher he was known as a stern but fairminded taskmaster, someone with a fondness for Latin American culture, an ability to bring a certain jocularity into the classroom, and a deep desire that the Latin American elements of United States culture be validated. As a contributing editor to the Handbook of Latin American Studies, he won the affection of many in the Hispanic Division of the Library of Congress, and his arrivals for research there were anticipated with excitement. Georgette Dorn, the Chief of the Division, and her staff looked forward to his conversations and the tales he brought with him of his latest travels. The numerous comments and letters received by the family from students and colleagues are a testament to their affection for a professor whose love of life's ironies and the pleasure of recounting the small triumphs of Latin Americans in the face of "El Gigante" came out in nearly every lecture. For my children, a trip to the Rodríguez household always was an adventure, and at least once it meant a trip to the circus.

I will always be grateful for the lessons he taught me about research and personal relations among academics. As my mentor, he introduced me to the Archivo General de Centro América in Guatemala City and formally helped me get accustomed to dealing with archivists, for which I was thankful. More informally, he inadvertently taught me a few lessons one does not learn in the seminar room. On one occasion after leaving the archive we retired to a bar on Sexta Avenida in downtown Guatemala City for late afternoon refreshments and reflection. By arrangement we were met by the late Louis Baumgartner, a fellow Central Americanist whose book Rod had recently reviewed with fulsome praise but for one minor quibble. As the refreshments multiplied, the tone of the conversation darkened ominously. It seems that Baumgartner took exception to the minor quibble in the review, and as the exchange of views grew heated I wondered who would first invite the other into the street where there was more room for physical expression of ideas. I also wondered how I might be able to explain this to the authorities. Miraculously, however, the passions calmed and before the evening ended the three of us were making our welloiled way arm-in-arm through Zona Tres along Avenida Elena, on our way home past an occasional dangerously-armed soldier on police duty, who seemed not to be enforcing Peralta Azurdia's toque de queda. That was my first well-earned lesson in book review writing. 
Mario Rodríguez is survived by Mildred (nee Shepherd), his wife of sixty-two years and herself an accomplished nutritionist, his daughter Jacqueline, son-in-law Wayne Mattice, and granddaughter Valerie. May his legacy endure.

Howard University

Vincent Peloso

Washington, D.C.

\section{RESEARCH ANNOUNCEMENT}

Proquest has released a new microfilm collection: "Central American Archives: From Colonialism to Independence, 1544-1821 (Rare Archival Documents from the Spanish Colonial Period)." The material in this collection comes from the General Archive of Central America (AGCA), in Guatemala City, and makes available the complete set of documents housed at McMaster University (Canada), with significant updates and consultations from the AGCA in Guatemala. Many of these documents are the only extant copy and this collection represents the first time these materials are available for commercial purchase in the United States. The collection contains six million pages of records (legislative, judicial, economic and religious) for six Central American provinces: Chiapas, El Salvador, Guatemala, Honduras, Nicaragua and Costa Rica, for the colonial period up to 1821. Libraries or individuals may acquire separate reels from the collection according to research needs, based on geographic region. Proquest is continuing to develop an index for the set, which is included in an online finding aid (http://wwwlib.umi.com/caa). Further information about the collection may be found via the Proquest website or by emailing Dennis Capraro (UMI Division of ProQuest Information \& Learning) at dennis.capraro@il.proquest.com

\section{BOOKS IN BRIEF}

Trade and Privateering in Spanish Florida, 1732-1763. By Joyce Elizabeth Harman. Introduction by Carl E. Swanson. Tuscaloosa, AL: University of Alabama Press, 2004. Pp. xx, 99. Maps. Notes. Appendices. Bibliography. Index. $\$ 16.95$ paper.

One of the most influential books ever written on the economy of colonial Florida is Joyce Elizabeth Harman's study Trade and Privateering in Spanish Florida, 1732-1763 (1969). In this new edition, Carl E. Swanson provides an introductory essay highlighting Harman as a forerunner of more recent books on the Atlantic world economy. Although Harman was not the first scholar to examine the role of trade in early Florida, she was the first to document Spanish Florida's relation to sea-going commerce.

Trade and Privateering is based on analysis of ship cargos and manifests, newspaper records and customs accounts, and disputes about the capture and confiscation of vessels. From this research a new picture of colonial life emerged. Harman's study 